\title{
Imaging the head: functional imaging
}

\author{
Guy V Sawle
}

If asked to choose between a brain that looked nice, or one that functioned well, most of us would choose the second. Furthermore, the ultimate importance of cerebral disease is that it affects brain function, not appearance. Yet clinical neuroimaging has been built around the practice of imaging brain structure. Why so? Because structural images are easier to acquire, and structure and function are so inextricably linked that one might as well image one as the other. But is this necessarily so? To what extent are structural and functional imaging processes independent of one another? And are there any clinical situations where structural imaging "just won't do"?

In this article I discuss several approaches to cerebral imaging in which the principal aim is to derive information about brain function. Specifically, I discuss positron emission tomography (PET), single photon emission computed tomography (SPECT), and functional magnetic resonance imaging (fMRI). Other functional imaging methods, such as blood flow measurements with ${ }^{133} \mathrm{Xe}-$ enhanced $\mathrm{CT}^{1}$ have been of considerable historical importance but are now seldom used in clinical or research practice and will not be covered further.

\section{Principles of the techniques}

POSITRON EMISSION TOMOGRAPHY (PET) ${ }^{2}$

In PET short lived isotopes are used to label molecules of biological interest. After inhalation or injection, they decay by positron emission, each positron becoming annihilated within 1-2 mm of its parent nucleus by collision with an electron. This annihilation generates two $\gamma$ rays (of $511 \mathrm{keV}$ energy) that travel apart at $180^{\circ}$ to one another. It is the nearly simultaneous detection of these $\gamma$ ray pairs by a ring of detector crystals that ultimately leads to the reconstructed image of isotope density. The theoretical limit of spatial resolution is the distance that positrons travel from their parent nucleus before annihilation. The actual spatial resolution depends in part on the size of detector crystals used in the camera. After positron annihilation deep within the brain, a percentage of the emitted photons fail to reach the detector crystals due to signal attenuation by brain tissue. In PET it is possible to correct for this loss using a second set of image data collected before isotope injection or inhalation. For this transmission scan an external (ring or moving rod) germanium-68 source is used. Current generation PET machines have a resolution of around $5 \mathrm{~mm}$ in the reconstructed image. Commonly employed PET isotopes include oxygen-15, carbon-11, and fluorine18 , used to replace the naturally occurring oxygen-16, carbon-12, and hydrogen-1 respectively in various biological molecules. This exchange of a radioactive atom for a naturally occurring atom results in little (if any) change in chemical behaviour. The half lives vary from two minutes (oxygen-15) to 110 minutes (fluorine-18). Such short half lives have both advantages (less radiation dose) and disadvantages (cost, dependence on an on site cyclotron for production, and the need for a tight time schedule). Measurements by PET take minutes to hours, depending on the particular brain function under scrutiny. Radiation considerations preclude frequent repeat measurements. The table gives an overview of some of the strengths and limitations of the PET method, together with comparative data for SPECT and fMRI.

SINGLE PHOTON EMISSION COMPUTED TOMOGRAPHY (SPECT) ${ }^{3}$

The isotopes used in SPECT (such as technetium-99 or iodine-123) have longer half lives, obviating the need for on site production. This reduces cost and eases some of the

Strengths and limitations of imaging methods

\begin{tabular}{|c|c|c|c|}
\hline & PET & SPECT & $f M R I$ \\
\hline Isotopes & $\begin{array}{l}\text { Fluorine-18, carbon-11 } \\
\text { oxygen-15 }\end{array}$ & $\begin{array}{l}\text { Technetium-99m } \\
\text { iodine-123 }\end{array}$ & None \\
\hline $\begin{array}{l}\text { Time per image } \\
\text { Spatial resolution }\end{array}$ & $\begin{array}{l}\text { Two minutes to two hours } \\
\text { About 5-6 mm }\end{array}$ & $\begin{array}{l}\text { Minutes to hours } \\
\text { About } 8 \mathrm{~mm}\end{array}$ & $\begin{array}{l}0.01 \text { Seconds to a few minutes } \\
0.75 \mathrm{~mm} \text { upwards } \\
\text { Yes }\end{array}$ \\
\hline Repeated studies & $\begin{array}{l}\text { Very few } \\
\text { (limited by radiation) }\end{array}$ & $\begin{array}{l}\text { Very tew } \\
\text { (limited by radiation) }\end{array}$ & \\
\hline Able to study & $\begin{array}{l}\text { Metabolism, blood flow, } \\
\text { receptor-ligand } \\
\text { interactions }\end{array}$ & $\begin{array}{l}\text { Blood flow, some } \\
\text { receptor-ligand } \\
\text { interactions }\end{array}$ & Blood flow/venous drainage \\
\hline Useful technical references & Phelps $^{2}$ & Lassen and Holm ${ }^{3}$ & Lufkin ${ }^{4}$; Stehling et $a l^{8}$ \\
\hline
\end{tabular}

Division of Clinical Neurology, Queens Medical Centre, Nottingham, NG7 2UH, UK G V Sawle 
timing restraints of PET. On the other hand, because they emit single $\gamma$ rays (hence single photon ECT), coincidence detection cannot be used to yield spatial information, which must, therefore, depend on collimation alone. Furthermore, signal attenuation by surrounding tissues cannot be corrected by an exact solution with transmission scan data as used in PET. Partly for the foregoing reasons, SPECT has a lower spatial resolution than PET. Nevertheless, because of the lower cost of SPECT and the greater availability of machines, SPECT has found an altogether larger place in the clinical arena than PET. Measurements by SPECT take minutes to hours. As with PET, radiation considerations preclude frequent repeat measurements.

\section{FUNCTIONAL MAGNETIC RESONANCE IMAGING (FMRI)}

In magnetic resonance methods, ${ }^{4}$ the divide between structural and functional imaging is precarious. For example, is magnetic resonance angiography (MRA) a functional or an anatomical measurement-because it shows the anatomy of the major cerebral vessels using a sequence that is specifically sensitive to the movement of the contained blood? In this review I use the term functional magnetic resonance imaging (fMRI) to refer to a range of $\mathrm{MR}$ sequences designed to acquire information about brain function. These techniques are newer than either PET or SPECT and the scientific literature concerned with their use has so far been more methodological than medical. Nevertheless, at least two fMRI approaches deserve mention-namely, echoplanar imaging (EPI), and fast low angle shot (FLASH) techniques. Each is concerned with the generation of images where a change in signal with time is most likely the consequence of changing neuronal function, the mediator between the two being a change in small vessel flow, or at least an increase in localised venous return. The present possibilities and imminent potentials of fMRI have been described in several recent reviews. ${ }^{5-7}$

Whereas the basics of PET and SPECT methodology follow parallel processes in other techniques such as photography and $x$ ray computerised tomography, MRI has no easy parallel in our other experiences. The fundamentals of magnetic resonance have been covered by Moseley in this fournal (1995;58:7-21); see also Lufkin ${ }^{4}$. Conventional MR sequences build up an image in steps, using a series of magnetic field gradients to specify anatomical positions within the tissue of interest. In EPI an image is recovered from the signal generated by a single free induction decay over a fraction of a second. ${ }^{8}$ On the other hand, FLASH sequences limit the time taken for scanning by minimising the perturbation of the magnetisation from its equilibrium so that successive excitation pulses can follow each other more quickly. Reported data from EPI at high ( 3 Tesla) field strength include images acquired in $0.1 \mathrm{~s}$ with a spatial resolution of $0.75 \mathrm{~mm} .{ }^{9}$ Despite the large number of MRI machines available for diagnostic purposes, few have either EPI or high (2-3 Tesla) field strength. It is possible to acquire FLASH fMRI images at a lower field strength (1.5 Tesla) with a "clinical" MR imaging system; although signal acquisition is in this case somewhat slower. ${ }^{10}$ All fMRI methods share one advantage over PET and SPECTnamely, the avoidance of ionising radiation.

\section{Practicalities of the techniques}

Because functional imaging studies have yet to enjoy wide use as clinical tools in routine neurological practice, the following account describes elements of the basic principles, as well as the nuts and bolts practicalities of patient scanning.

\section{PET}

General principles

The general principle of the PET measurement requires a mathematical model that corresponds to the functional system under scrutiny. This model is an approximation of the processes that lie between the "input" (the activity given to the patient and available to the brain via its arterial supply or by inhalation) and the "output" (the activity measured regionally during the course of the experiment).

\section{Cerebral blood flow}

One of the simplest PET models relates to the measurement of regional cerebral blood flow during continuous inhalation of $\mathrm{C}^{15} \mathrm{O}_{2}$. After a few minutes inhalation, an equilibrium is reached whereby the arterial supply of radioactivity to the brain is equal to the loss of activity from venous washout and radioactive decay (the so called steady state condition). In this situation a simple mathematical expression describes the regional cerebral blood flow in terms of known or measurable values-namely, the radioactive decay constant (fixed for ${ }^{15} \mathrm{O}$ ), the arterial activity of $\mathrm{H}_{2}{ }^{15} \mathrm{O}$ (in $\mu \mathrm{Ci} / \mathrm{ml}$, measured in an arterial blood sample with a well counter), and the regional brain concentration of tracer in units/ml (measured in the PET camera). The steady state measurement of regional cerebral blood flow takes about 15 minutes to complete.

On the practical side, these measurements (and all of those listed below) require that the patient be still during image acquisition. They require a venous line for tracer administration (except when $\mathrm{C}^{15} \mathrm{O}_{2}, \mathrm{C}^{15} \mathrm{O}$, or ${ }^{15} \mathrm{O}_{2}$ are given by inhalation). Most quantitative studies also require an arterial line to measure the level of radioactivity presented to the brain over the time course of the scan.

Blood flow can also be measured during the rise and fall of brain radioactivity surrounding a bolus inhalation or injection of tracer. The mathematical model required to unscramble the collected data to a measured value for $\mathrm{rCBF}$ is in this case very much more complicated, ${ }^{11}$ but the method is faster (data acquisition takes only two to three minutes). 
Oxygen metabolism

Oxygen metabolism can be calculated from cerebral blood flow after additional measurements of the oxygen extraction fraction (the percentage of the available blood oxygen extracted during its passage through the brain vasculature; usually measured after inhalation of ${ }^{15} \mathrm{O}_{2}$ ) and regional blood volume (a correction for the percentage of any cerebral region that contains blood rather than brain). ${ }^{12}$ Such a (triple) measurement with steady state models takes about 40 minutes (including time for radioactive decay between scans).

\section{Glucose metabolism}

Glucose metabolism is measured after intravenous injection of $2-\left[{ }^{18} \mathrm{~F}\right]$ fluoro-2-deoxy-Dglucose (FDG), which is metabolised by hexokinase to FDG-6-phosphate. As FDG-6phosphate can neither proceed down the glycolytic pathway nor be metabolised to glycogen (the metabolic destinies for glucose6-phosphate) it stays trapped within the tissue for the duration of the PET measurement. This compartmental trapping is the cornerstone of the FDG measurement. Further interpretation may be fully quantitative (requiring continuous arterial and regional cerebral radioactivity measurements) or semiquantitative (using normative data from other subjects, and a further series of constants and restraints in the employed mathematical model). On the practical side this means that for the most accurate measurement, a patient must be in the camera during tracer injection and for the next 60 to 90 minutes, with simultaneous arterial blood sampling. For a less quantitative scan (from which regional inequalities in glucose metabolism can yet be semiquantified). the tracer can be injected out of the camera and a "snapshot" image (lasting perhaps 15 minutes) can be taken about 30 to 40 minutes later.

Neurotransmitter precursor studies

Aside from blood flow and measures of tissue metabolism, the other principal application of PET to date has been in neuropharmacological studies; PET has a small repertoire for the study of neurotransmitter synthesis and storage, principally the decarboxylation of $\left[{ }^{18} \mathrm{~F}\right]$ dopa to $\left[{ }^{18} \mathrm{~F}\right]$ dopamine. Like the FDG method, the premise on which most of the $\left[{ }^{18} \mathrm{~F}\right]$ dopa analytical methods are based is the assumption that the injected tracer $\left(\left[{ }^{18} \mathrm{~F}\right] \mathrm{dopa}\right)$ is transported into the brain and then specifically taken up by dopamine neurons where it is decarboxylated, concentrated, and then stored in nerve terminal vesicles for the duration of the measurement. A particular disadvantage of $\left[{ }^{18} \mathrm{~F}\right]$ dopa as a tracer of the dopamine synthetic pathway is that the concentration of the endogenous (dopa) pool is unknown. So if anybody ever discovers the perfect mathematical model to unravel $\left[{ }^{18} \mathrm{~F}\right]$ dopa scan data (an endeavour that has attracted much energy, even some disagreement) they will still only have measured the rate of metabolism of exogenous $\left[{ }^{18} \mathrm{~F}\right] \mathrm{dopa}$; the rate of endogenous dopamine production cannot be deduced without a knowledge of the endogenous dopa pool-which you can't measure! Despite these caveats, $\left[{ }^{18} \mathrm{~F}\right]$ dopa has been an excellent work horse in the PET armamentarium.

\section{Neurotransmitter receptor studies}

Tracers of much larger variety have been employed as markers for particular classes of neurotransmitter receptor, including dopamine D1 $\left(\left[{ }^{11} \mathrm{C}\right] \mathrm{SCH} 23390^{13}\right)$ and D2 $\left(\left[{ }^{1} \mathrm{C}\right]\right.$ raclopride $\left.^{14}\right)$ postsynaptic receptors, dopamine reuptake sites $\left(\left[{ }^{11} \mathrm{C}\right]\right.$ nomifensine ${ }^{1516}$ and $\left.\left[{ }^{11} \mathrm{C}\right] \mathrm{WIN}-35,428^{17}\right)$ opiate receptors (mu, $\left(\left[{ }^{11} \mathrm{C}\right]\right.$ carfentanil $\left.{ }^{18}\right), \mathrm{mu}$ and kappa $\left(\left[{ }^{18} \mathrm{~F}\right]\right.$ cyclofoxy $\left.{ }^{19}\right)$, mu, kappa, and delta $\left(\left[{ }^{11} \mathrm{C}\right]\right.$ diprenorphine $\left.\left.{ }^{20}\right)\right)$, central $\left(\left[{ }^{11} \mathrm{C}\right] \mathrm{flu}\right.$ mazenil $\left.{ }^{21}\right)$ and peripheral $\left(\left[{ }^{11} \mathrm{C}\right] \mathrm{PK} 11195^{22}{ }^{23}\right)$ benzodiazepine receptors, muscarinic cholinergic receptors $\left(\left[{ }^{11} \mathrm{C}\right]\right.$ scopolamine $\left.{ }^{24}\right)$, histamine $\mathrm{H} 1$ receptors $\left(\left[{ }^{11} \mathrm{C}\right]\right.$ pyrilamine $\left.{ }^{25}\right)$, and MAO-B activity $\left(\left[{ }^{11} \mathrm{C}\right]\right.$ deprenyl $\left.{ }^{26}\right)$. These ligands have been used (some extensively) to study the changes in receptor numbers or affinity in some disease states, including Parkinson's and other akinetic rigid syndromes, Huntington's disease, epilepsy, pain, and stroke. Quantitative measurements require continuous measurement of blood and brain activity during and after injection of tracer. A single PET scan may be sufficient for semiquantification, but if a full description in neuropharmacological terms is required (to calculate, for example, $B_{\max }$, the total concentration of binding sites) repeat studies may be necessary in the same subject with injections of tracer having different specific activities, or coinjection of unlabelled tracer.

\section{Functional mapping}

Aside from neurotransmitter studies, the other growth area in recent years has been the development of functional mapping studies in which repeat measurements of blood flow are used as a means of identifying brain regions active in particular cognitive or other prescribed tasks. If a subject is scanned twice, once at rest and the second time during right arm movement, it is argued that any difference between the two images of blood flow may be accounted for either by noise, by artefact, by a general (global) effect of the activity on cerebral blood flow, or by a specific activation of a responsible brain region. Various methods have been developed to extract the specific information by removing the confounding effects. ${ }^{2728}$ In large part the published base of work in this area has employed between subject averaging to improve the signal to noise characteristics of the method. Newer scanners with MRI coregistration allow more confident results in individual subjects with greater accuracy in the anatomical loci of activation related change. ${ }^{29}$ The use of functional mapping studies have not so far been reported as a clinical procedure.

SPECT

General principles

The practicalities of SPECT measurements 
are for the most part simpler than for PET. In part this is because SPECT data are by necessity less quantitative than PET data. Another relevant factor may be the closer liaison and relation between SPECT and clinical medicine, with the restraining hand of clinical practicality curbing the imager's urge to add complexity in the pursuit of accuracy.

Cerebral blood flow

The SPECT approach to cerebral blood flow hinges on the finding that certain tracers are irreversibly taken up into the brain in a regional pattern that reflects localised differences in cerebral blood flow. After intravenous injection, $\left[{ }^{123} I\right]-n$-isopropyl amphetamine $\left(\left[{ }^{123} \mathrm{I}\right]\right.$-iodoamphetamine) ${ }^{30}$ crosses the blood-brain barrier by passive diffusion with a high first pass extraction. It is then retained in the brain by non-specific binding to amine receptors. So signal intensity in a "snapshot" image taken 20 to 60 minutes after tracer injection is proportional to the perfusion dominated distribution of tracer in the brain.

Likewise, [ $\left.{ }^{99 \mathrm{~m}} \mathrm{Tc}\right]$ hexamethylpropyleneamine oxime ([$\left.\left.{ }^{99 \mathrm{~m}} \mathrm{Tc}\right] \mathrm{HMPAO}\right)$ crosses the blood-brain barrier easily by passive diffusion. It is then trapped in the brain (after decomposition to a byproduct that cannot pass back across the barrier), uptake and trapping being complete within 10 minutes. Images taken 90 to 120 minutes after injection (image acquisition typically taking about 20 minutes) still show the frozen image of regional cerebral blood flow at the time of tracer administration. [ $\left.{ }^{99 \mathrm{~m}} \mathrm{Tc}\right] \mathrm{HMPAO}$ is preferred to $\left[{ }^{123} \mathrm{I}\right]$-iodoamphetamine on several accounts, including its optimum imaging energy and shorter half life. Unlike PET blood flow measurements, which require an on site cyclotron, [ $\left.{ }^{99 \mathrm{~m}} \mathrm{Tc}\right] \mathrm{HMPAO}$ can be produced in a hospital nuclear medicine department with a molybdenum-99 generator. It must be used within about 30 minutes of production to avoid decomposition before injection. [99m Tc] labelled N,N"'-1,2-ethylene-diylbis-Lcysteine diethyl ester dihydrochloride ([99m Tc]ECD) is similar to but more stable than [ ${ }^{99 m}$ Tc] HMPAO. ${ }^{31}$

Patients undergoing SPECT measurement of cerebral blood flow with these techniques do not need to be in the camera during tracer injection. They should, however, be rested at this time because it is blood flow around the time of injection that is measured during the later scan, not blood flow at the time of the measurement, as in PET.

For the most part, the interpretation of SPECT flow images follows the radiological tradition-namely, interpretation of the image appearance by an expert in the field. As with the assessment of age related atrophy on structural images, the observer must take into account the known changes in cerebral blood flow that accompany the normal ageing process. Such images are often reported alongside structural images to help in the differentiation between normal and pathological appearances.
Neurotransmitter receptor studies

Several neurotransmitter systems have been studied with SPECT. Specifically the dopamine D2 ligand [ $\left.{ }^{123} \mathrm{I}\right]-(\mathrm{S}-)-2$-hydroxy-3iodo-6-methoxy-N [(1-ethyl-2-pyrrolidinyl) methyl]-benzamide ([123I]-iodobenzamide) has been extensively used in neurological disorders. This ligand binds reversibly to dopamine D2 receptors. The amount of specific striatal binding increases over about 40 minutes and then remains stable for up to two hours. Typically data are acquired during the period 60 to 120 minutes after tracer injection, image acquisition taking about 50 minutes. Because of the limitations of measurement, SPECT [ $\left.{ }^{123} \mathrm{I}\right]$-iodoamphetamine data are reported as a specific : non-specific ratio, such as striatum:cerebellar counts.

\section{fMRI}

\section{General principles}

Procedures for $\mathrm{fMRI}$ are very different from either PET or SPECT, being independent of ionising radiation. Aside from any activity that the patient might be asked to perform while in the magnet, the patient's experience of fMRI is unlikely to differ greatly from any other MR procedure (loud noises in a dark tunnel), although EPI imaging is presently particularly noisy. Although rapid MR sequences (such as EPI) yield clear images of moving structures (such as a beating heart or a waving head) fMRI methods rely on a comparison of successive scans of the same area. In this case, the head position must be identical for the acquisition of each of the images contributing to data analysis. Even the tiniest head movements can wreck havoc with fMRI analysis; indeed it has even been possible to create striking "functional" data as a result of head movement artefact alone. ${ }^{32}$ As with PET, one approach to the problem of head movement between scans may be to realign the data in software after image acquisition. ${ }^{33} 34$

\section{What has been learned with these techniques, and to what extent may they be used in clinical practice?}

Both PET and SPECT have been used in neuroscience research to examine brain function in health and in disease. Thus far fMRI has been most closely applied to the study of healthy subjects, although this will certainly change. This review will concentrate on those studies designed primarily to answer questions about disease. When applicable, mention will be made of clinical situations in which functional imaging could provide valuable additional information. The United Kingdom has a single PET research institution (the Medical Research Council Cyclotron Unit at the Hammersmith Hospital) and a single dedicated clinical PET facility (at the St Thomas' and Guy's Hospitals). The first has a broad range of chemistry facilities, whereas the available ligands in the clinical PET centre are fewer. This pattern is generally true elsewheremost PET centres with clinical services 
chiefly offer $\left[{ }^{18} \mathrm{~F}\right]$ fluorodeoxyglucose scans; other more closely research based units typically have a more extended repertoire. In the United States there is now an Institute for Clinical PET. Furthermore, some United States health insurance schemes have approved a variety of clinical PET procedures for reimbursement. Presently, SPECT scanners are more widely distributed, both in the United Kingdom and elsewhere. Although many hospital radiology departments are equipped with magnetic resonance machines, few have the hardware and software on hand for the acquisition of an fMRI signal.

\section{CEREBROVASCULAR DISEASE}

Early PET studies measured regional cerebral blood flow, blood volume, oxygen extraction, and oxygen metabolism to examine the pathophysiology of stroke, particularly the mechanisms of cerebrovascular compensation in the face of falling and failing arterial perfusion pressure. ${ }^{35} 36$ Currently PET and SPECT can both detect cerebral ischaemia in acute stroke at a stage when CT images are still normal. It has been shown that PET also has some ability to predict the extent of functional recovery from stroke ${ }^{37}$ and in recovered patients (using functional mapping) it can show the anatomical and functional substrate of recovered function. ${ }^{38} 39$ Likewise PET and SPECT can show evidence of hypoperfusion ("misery perfusion") in the absence of infarction, ${ }^{40}$ and hyperperfusion ("luxury perfusion") at a site of previous infarction. Haemodynamic changes can be shown by PET in patients after extracranial-intracranial bypass operations. ${ }^{41}$ Although this operation has not been shown to be of benefit in large interventional studies $^{42}$ it is possible that preoperative functional imaging could be used to identify patients more likely to gain from operation.

Basic research in cerebrovascular disease has given cause for guarded optimism over the possible use of cerebral protective agents such as glutamate antagonists and free radical scavengers; PET is waiting in the wings to be used to increase the pathophysiological and therapeutic gains from patient trials with these agents. Whether it will be called on remains to be seen

\section{CLINICAL INDICATIONS}

There are presently no consensus indications for the clinical use of functional imaging in cerebrovascular disease (but then there are no clinically proved treatments for acute stroke either ${ }^{43}$; both could change).

\section{DEMENTIA}

Early PET studies showed regional metabolic changes in Alzheimer's disease and some other degenerative conditions, and these findings led to the notion that particular diseases might be recognisable by specific regional changes in cerebral function. As in the study of several other disease states, many of the early reports of functional imaging in Alzheimer's disease included small numbers of patients and employed loose diagnostic criteria. Results were sometimes contradictory. Consensus has now been reached in a number of areas as follows. In Alzheimer's disease, the brunt of the early PET changes are centred around the posterior temporal and parietal cortices (fig 1). ${ }^{44-47}$ Regional between patient differences may correlate with differences in neuropsychological test scores. ${ }^{45} 4849$ Changes on PET may antedate clinical dementia in patients presenting with mild memory deficits. ${ }^{50}$ Studies with SPECT in Alzheimer's disease have also shown reduced

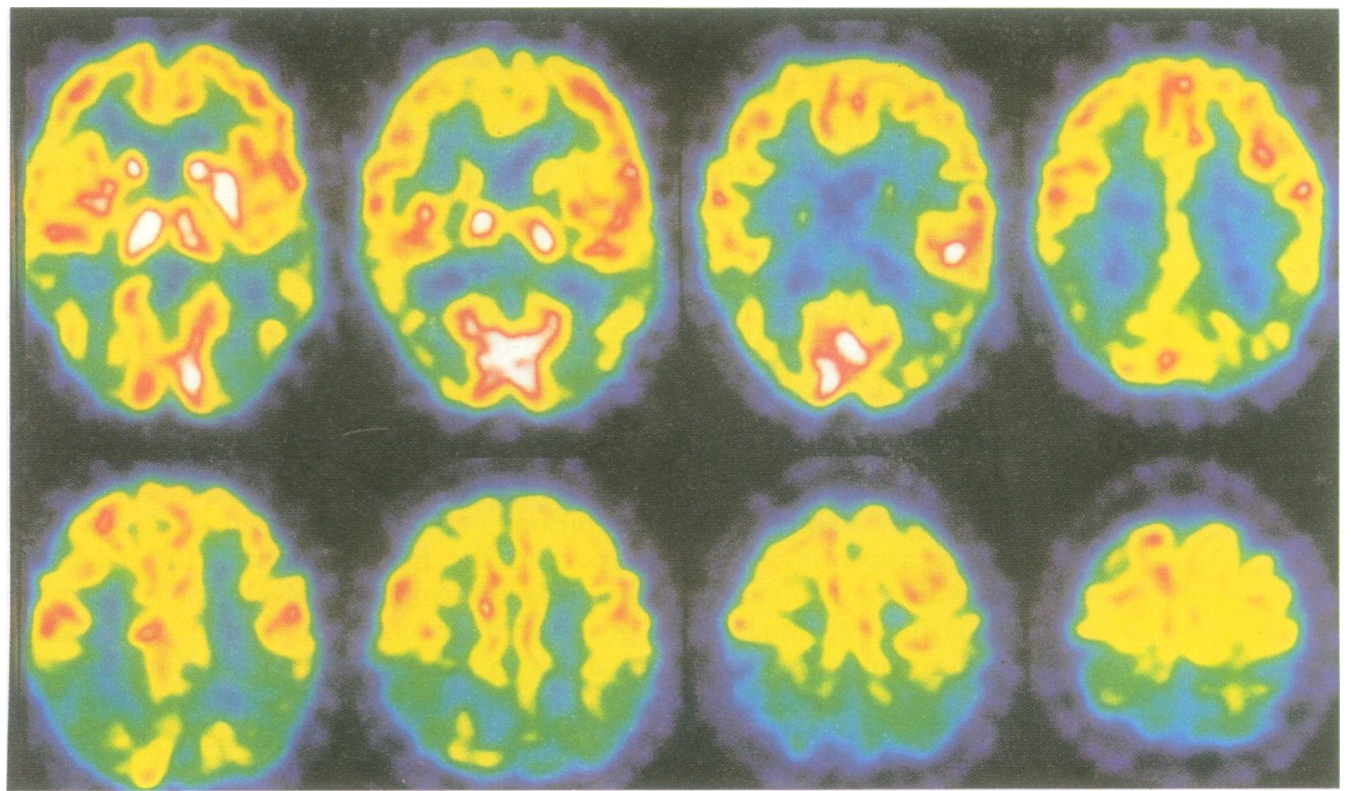

Figure 1 PET image of $\left.{ }^{8} \mathrm{~F}\right]$ fluorodeoxyglucose metabolism in Alzheimer's disease. Note reduced tracer uptake in posterior temporal and parietal cortex. (Picture courtesy of $\operatorname{Dr} A$ Kennedy.) 
flow in posterior temporal and other cortical regions. ${ }^{51-53}$ In patients with familial Alzheimer's disease $\left[{ }^{18} \mathrm{~F}\right]$ fluorodeoxyglucose PET in affected family members shows the same pattern of parietotemporal hypometabolism. Scans in asymptomatic at risk relatives show a similar (but less severe) pattern. ${ }^{54}$

Most PET scans in patients with Pick's disease established by necropsy or biopsy have shown predominantly frontal hypometabolism. ${ }^{556}$ This finding is not specific to Pick's disease, however, as it has also been reported in progressive supranuclear palsy ${ }^{57-59}$ and SPECT studies have shown a reduction in frontal $\left[{ }^{99 \mathrm{~m}} \mathrm{Tc}\right]$ HMPAO uptake in patients presenting with dementia of the frontal lobe type. ${ }^{60}$

Patients with focal cortical degenerations presenting with slowly progressive apraxia or aphasia have been studied with PET and have been shown to have appropriate areas of cortical hypometabolism at a stage when structural imaging studies have been normal. ${ }^{6162}$ The pathology in these patients turns out to be variable. Much has been written about the identification of clinical and preclinical changes in PET metabolic indices in Huntington's disease. ${ }^{63-66}$ Both striatal and cortical hypometabolism have been reported. After the demonstration of low caudate $\left[{ }^{18} \mathrm{~F}\right]$ fluorodeoxyglucose metabolism in some at risk patients, considerable efforts were directed towards the development of PET as a preclinical disease marker. ${ }^{6566}$ Although genetic testing now provides a generally reliable means of making a positive diagnosis of Huntington's disease based on a blood sample alone, ${ }^{6768}$ it may be that PET still has a part to play in these patients. If, for example, neurotransplantation procedures become a practical proposition in this disorder, it may be that PET will provide a crucial means of identifying an appropriate preclinical or early clinical stage of disease for intervention. Gene positive at risk patients have lower striatal and pallidal volumes (a structural MR measurement) than gene negative at risk patients ${ }^{69}$; it has yet to be shown that either MRI or PET can indicate when an at risk subject will develop clinical problems. Neurotransmitter studies in the foregoing conditions are discussed in the next section.

\section{CLINICAL INDICATIONS}

As with cerebrovascular disease, there are presently few if any treatment options that could reasonably be said to depend on diagnostic information that could only be gleaned from functional imaging studies. Both PET and SPECT may assist in the accurate diagnosis of these conditions presenting as a dementing illness; but such data cannot yet be regarded as mandatory in good patient care.

\section{MOVEMENT DISORDERS}

In Parkinson's disease, early blood flow and metabolic studies ${ }^{70-72}$ were soon upstaged by the demonstration of reduced striatal uptake of $\left[{ }^{18} \mathrm{~F}\right]-6$ - $\mathrm{L}$-fluorodopa $\left(\left[{ }^{18} \mathrm{~F}\right]\right.$ dopa) in affected patients. ${ }^{73}$ Many $\left[{ }^{18} \mathrm{~F}\right]$ dopa studies have now been reported in this disorder, considering issues such as the role of ageing (most centres, ${ }^{74} 75$ but not all, ${ }^{76}$ have shown no effect of age on $\left[{ }^{18} \mathrm{~F}\right]$ dopa uptake), the detection of presymptomatic disease (fig 2), ${ }^{77}$ the rate of progression of clinically evident disease, ${ }^{78-80}$ and the efficacy of neurotransplantation procedures (fig 3). ${ }^{81} 82$

Various other akinetic rigid conditions have been studied by $\left[{ }^{18} \mathrm{~F}\right]$ dopa PET, including multiple system atrophy, ${ }^{83-85}$ progressive supranuclear palsy, ${ }^{578384}$ corticobasal degeneration, ${ }^{86}$ neuroacanthocytosis, ${ }^{87}$ and 1-methyl4-phenyl-1,2,3,6-tetrahydropyridine (MPTP) parkinsonism. ${ }^{8288}$ Some of these disorders have been reported to show characteristic



Figure 2 PET image to show $\left[{ }^{8} F\right]$ dopa uptake in a normal subject (left), a patient with idiopathic (sporadic) Parkinson's disease, and two members of a sibship with familial parkinsonism. The symptomatic patient shows profoundly impaired fluorodopa uptake whereas the presymptomatic subject (who became clinically affected within months of the scan) shows fluorodopa uptake at a level intermediate between normal and parkinsonian values. 
Figure 3 Combined MRI (T1 weighted) and PET ( $\left.{ }^{8} \mathrm{~F}\right]$ dopa) image from a parkinsonian patient who has undergone implantation of fetal material into the putamen. The MRI image shows the site of the burr hole and

three needle tracks reaching down through the cortex and subcortical white matter into the putamen. The $\left.{ }^{18} \mathrm{~F}\right]$ dopa image shows uptake at the graft site.



patterns of striatal $\left[{ }^{18} \mathrm{~F}\right]$ dopa uptake, such as severe asymmetric loss of caudate and putamen uptake (in corticobasal degeneration ${ }^{86}$ ) or severe bilateral early loss of both caudate and putamen signal (in progressive supranuclear palsy $\left.{ }^{84}\right)$. The difficulty in translating these patterns from research to clinical practice is that these studies have of course been undertaken in patients who carry a (fairly) confident clinical diagnosis. Even in such patients, if we move from a group to individual subjects and study their $\left[{ }^{18} \mathrm{~F}\right]$ dopa PET data, it may be impossible to ascribe a particular diagnosis (for example Parkinson's disease $v$ multiple system atrophy) with absolute certainty. ${ }^{89}$

$\left[{ }^{18} \mathrm{~F}\right]$ Dopa studies have also been performed in possibly less obvious disorders. It has been shown that the extrapyramidal symptoms in clinically diagnosed Alzheimer's disease seem not to be due to nigral degeneration. ${ }^{90}$ The motor disorders in obsessional slowness $^{91}$ and manganese toxicity ${ }^{92}$ are likewise unaccompanied by changes in $\left[{ }^{18} \mathrm{~F}\right]$ dopa uptake, whereas in patients poisoned by cyanide $\left[{ }^{18} \mathrm{~F}\right]$ dopa uptake is reduced, suggesting (direct or hypoxic induced) nigral toxicity. ${ }^{93}$ Patients with parkinsonism resulting from neuroleptic or other dopamine blocking drugs may have either normal $\left[{ }^{18} \mathrm{~F}\right]$ dopa uptake (suggesting a likely return to clinical normality after cessation of the offending agent) or low uptake (suggesting unmasking of otherwise subclinical parkinsonism..$^{94}$

$\left[{ }^{18} \mathrm{~F}\right]$ dopa is not the only tracer to provide information about the presynaptic dopamine system. [ $\left.{ }^{11} \mathrm{C}\right]$ Nomifensine has also been used (as a marker of catecholaminergic presynaptic reuptake sites) but in most cases the results of [ $\left.{ }^{11} \mathrm{C}\right]$ nomifensine studies have closely paralleled those with $\left[{ }^{18} \mathrm{~F}\right]$ dopa. ${ }^{169}$ Cocaine ana- logues such as $\left[{ }^{11} \mathrm{C}\right] \mathrm{CFT}$ (also known as WIN 35 428) have also been used to study the dopamine fibre system. In a primate model of parkinsonism, $\left[{ }^{11} \mathrm{C}\right] \mathrm{CFT}$ uptake was reduced in the striatum. ${ }^{96}$ This ligand has the advantage of a substantially higher striatal to background signal than $\left[{ }^{18} \mathrm{~F}\right]$ dopa, but the kinetics are, if anything, a little slow for use as a PET tracer. The related compound, CIT, has been uptake of this tracer was reduced in Parkinson's disease. ${ }^{97}$

In part, the answer to the problem of differential diagnosis by PET in individual patients might be helped by multiple tracer studies to examine receptor status as well as (or in place of) $\left[{ }^{18} \mathrm{~F}\right]$ dopa uptake. There are many publications concerning dopamine D2 receptors in akinetic-rigid syndromes. On balance PET and SPECT studies suggest relative upregulation of $\mathrm{D} 2$ receptors in patients with early Parkinson's disease, with normal or even lower levels later in disease; perhaps in part as an effect of treatment with dopaminergic drugs (PET ${ }^{148798-101} ;$ SPECT ${ }^{102-104}$ ). Patients with multiple system atrophy are more likely to have low D2 ligand binding $\left(\mathrm{PET}^{14}{ }^{84}\right)$ and low tracer uptake in dopa naive akinetic-rigid patients may predict subsequent evolution to multiple system atrophy rather than Parkinson's disease (PET ${ }^{14}$; SPECT ${ }^{105}$ ) (fig 4). Unlike the D2 system, PET studies of dopamine D1 receptors have shown no evidence of up regulation in early levodopa naïve patients. ${ }^{13}$ Other neurotransmitter receptors have also been studied in akinetic-rigid syndromes. Specifically, striatal $\left[{ }^{11} \mathrm{C}\right]$ diprenorphine binding has been shown to be impaired in patients with multiple system atrophy, but not in patients with Parkinson's disease. ${ }^{106}$ In a study using used in SPECT as $\left.\left[{ }^{123}\right]\right]$-CIT. Striatal 
Figure 4 SPECT [23I] iodobenzamide binding in a patient with Parkinson's disease (left) and a patient with a non-dopa responsive parkinsonian syndrome

(right). (Picture courtesy of Drs $K$ Tatsch and $\mathcal{F}$

of Drs $K$ Tatsch and $\mathcal{F}$
Schwarz, Department of Nuclear Medicine and Neurology, University of Munich.)

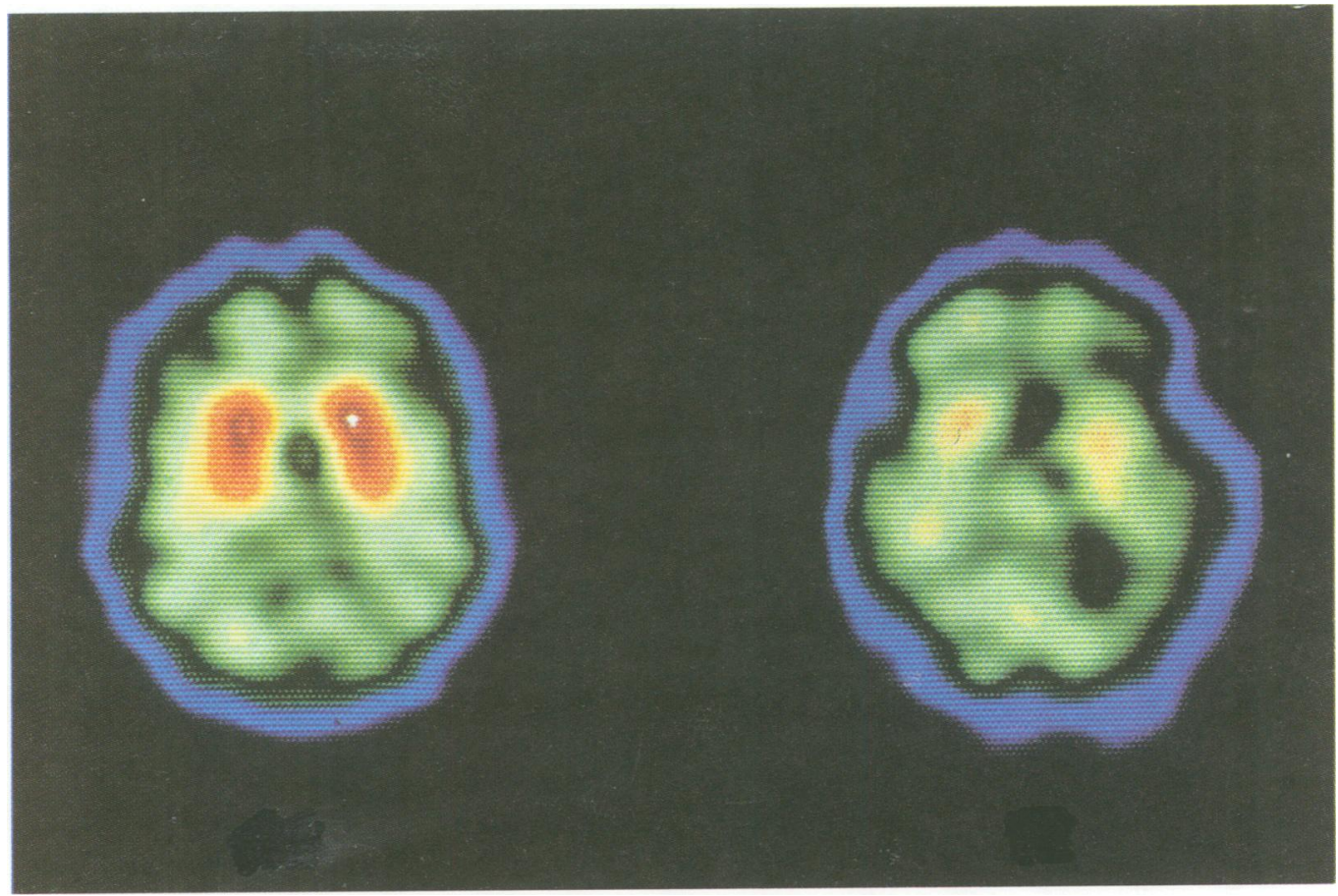

$\left[{ }^{11} \mathrm{C}\right]$ flumazenil as tracer to measure cerebellar GABA-A/benzodiazepine receptors, increased tracer binding was reported in patients with multiple system atrophy, whereas patients with sporadic and dominantly inherited olivopontocerebellar atrophy had increased and unchanged binding respectively. ${ }^{107}$

Although neurotransmitter studies occupy most of the literature on functional imaging in akinetic-rigid syndromes, specific focused metabolic studies and more recent functional mapping papers are starting to redress the balance. In depressed parkinsonian patients, for example, a particular pattern of frontal hypometabolism has been found. ${ }^{108}$ Also, with more sophisticated statistical techniques, some correlations have been reported between regional metabolic changes, motor asymmetries, and fluorodopa uptake constants. ${ }^{109}$ Functional mapping studies have shown failure of supplementary motor cortex activation during internally generated movements in parkinsonian patients ${ }^{110}$ with resolution towards the normal after dopamine agonist treatment (shown both with PET ${ }^{111}$ and SPECT ${ }^{112}$ ). More recently, fMRI studies have begun to consider this same issuenamely, the identification of cortical areas responsible for the control of human movement. ${ }^{113114}$ Reported fMRI findings in this area include a positive relation between movement rate and the fMRI signal in the primary motor cortex, ${ }^{114}$ and a greater signal intensity in supplementary motor areas during complex self paced movements than during externally paced movements. ${ }^{113}$

Although most PET studies in Huntington's disease have used $\left[{ }^{18} \mathrm{~F}\right]$ fluorodeoxyglucose as the tracer, more recent attention has focused on the dopamine sys- tem. Dopamine D1 and D2 receptors have each been studied in affected patients (with $\left[{ }^{11} \mathrm{C}\right] \mathrm{SCH} 23390$ and $\left[{ }^{11} \mathrm{C}\right]$ raclopride as tracers). Affected patients show a reduction of both D1 and D2 binding potentials (fig 5). ${ }^{115}$ With $\left[{ }^{11} \mathrm{C}\right]$ raclopride PET, asymptomatic gene positive subjects may show an intermediate reduction in binding potential ( $R$ Weeks, personal communication).

At the time of writing, fMRI studies have yet to be reported in patients with Parkinson's disease or other movement disorders.

\section{CLINICAL INDICATIONS}

What of the clinical utility of functional imaging in movement disorders? Despite the scientific findings discussed, no clear necessity for such imaging studies has yet been shown. In part, this relates to the lack of available treatment for many of these disorders. In akinetic-rigid syndromes for example, some, but not all, patients respond to levodopa or dopamine agonists. Although there is little effective treatment for those patients who are resistant to such treatment, informed trial and error seems as good a therapeutic approach as functional imaging. A special exception to this rule might be argued for dopa responsive dystonia. Patients with this disorder gain long term benefit from levodopa without developing the side effects and complications that bedevil patients with Parkinson's disease, ${ }^{116}$ particularly those with onset early in life. ${ }^{117}$ Fluorodopa uptake in dopa responsive dystonia is close to normal, ${ }^{118119}$ but it is profoundly impaired in patients with young onset (age 20-40) or juvenile onset (before age 20) Parkinson's disease. ${ }^{120}$ A highly abnormal $\left[{ }^{18} \mathrm{~F}\right]$ dopa PET scan in a young patient with an akinetic-rigid syndrome would therefore imply a likelihood of early problems with 


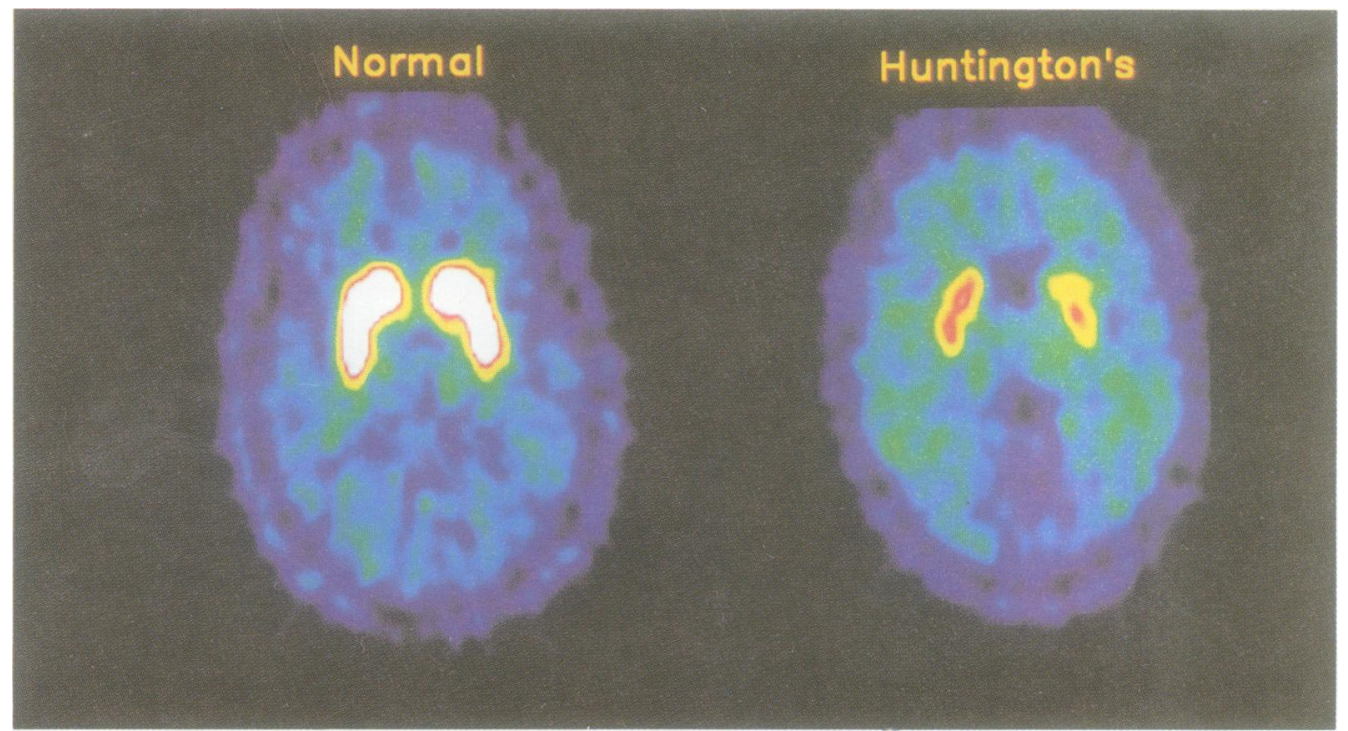

Figure 5 PET [ $\left[{ }^{\prime} C\right]$ raclopride images from a normal subject (left) and a patient with Huntington's disease (right). Note profoundly reduced tracer uptake in the striatum of the patient with Huntington's disease. (Picture courtesy of $\operatorname{Dr} R A$ Weeks.)

levodopa treatment, whereas early treatment with levodopa would be appropriate in a patient in whom $\left[{ }^{18} \mathrm{~F}\right]$ dopa PET showed uptake close to or in the lower normal range.

Patients undergoing experimental neurotransplantation procedures may also gain some direct personal benefit (graft site selection, for example) ${ }^{81}$ but otherwise for now, the principal promise of functional imaging in movement disorders is in the advancement of our understanding of disease, causation, and treatment.



Figure 6 SPECT ${ }^{99 m}$ Tc] HMPAO images from a four year old child with partial motor seizures. The interictal image shows hypometabolism in the left hemisphere. The ictal image shows an area of hypermetabolism corresponding to the seizure focus. (Picture courtesy of Dr $\mathcal{F} H$ Cross.)

\section{EPILEPSY}

In patients with focal epilepsy, functional imaging studies (PET and SPECT) have shown evidence of interictal focal hypometabolism (fig 6). ${ }^{121-123}$ In some cases it has been possible to scan patients during seizures, in which case areas that are interictally hypometabolic may become ictally hypermetabolic or show high flow. ${ }^{122} 124125$ It has been reasonably argued that such regions represent epileptic foci, even in the absence of corroborative findings from structural imaging or EEG. In patients with intractable epilepsy, surgical excision of a definite seizure focus may radically improve clinical status. Current MRI techniques are able to identify structural abnormalities in an increasing number of such patients. There are, nevertheless, a significant number of patients in whom noninvasive means fail to clearly identify a seizure focus. Options in these patients include the placement of depth electrodes and functional imaging studies.

In a comparative study of $\left[{ }^{18} \mathrm{~F}\right]$ fluorodeoxyglucose PET and [99m Tc]HMPAO SPECT in patients undergoing investigation before surgery for temporal lobe epilepsy, different sensitivities were reported for the two techniques. In patients who had a normal MRI, PET with $\left[{ }^{18} \mathrm{~F}\right]$ fluorodeoxyglucose showed focal hypometabolism in $80 \% v 20 \%$ for SPECT with [ $\left.{ }^{99 \mathrm{~m}} \mathrm{Tc}\right] \mathrm{HMPAO} .{ }^{126}$ The authors attributed this difference to the greater spatial resolution of the PET technique. Although PET is a potentially quantitative technique, it has been argued that for clinical epileptology purposes, image inspection by experienced eyes is generally sufficient. ${ }^{127}$

In another study of patients with intractable epilepsy, SPECT detected lateralising abnormalities in 19 of 30 patients; only two further lateralised abnormalities were 
found with CT or MRI. ${ }^{128}$ As in many other areas of imaging the ground is shifting rapidly. With increasing structural resolution in MRI (including hippocampal volume measurements) the balance is swinging in favour of MRI having a greater chance of correct lateralisation than SPECT. ${ }^{69}$

A recent fMRI study of a four year old boy showed changes in image signal restricted to an area of structural abnormality during five seizures over a 25 minute period. Interictal SPECT showed reduced [ ${ }^{99 \mathrm{~m}} \mathrm{Tc}$ ]HMPAO uptake in the same region, whereas increased uptake was found during a seizure. ${ }^{129}$

\section{CLINICAL INDICATIONS}

Both interictal and ictal functional imaging studies may show areas of abnormal signal in patients with focal epilepsy. This localisation is appropriately used to confirm or refute collateral evidence from structural $M R I$ and EEG examinations in the assessment of patients with refractory epilepsy who are being considered for surgical treatment (usually a partial temporal lobectomy).

\section{ONCOLOGY}

Most cerebral tumours are easily seen by structural imaging, which typically shows the lesion location, morphological details, evidence of damage to the blood-brain barrier, and induced cerebral oedema. From these data it is often possible to reach an accurate prediction of tumour type and likely histology. Functional imaging studies can add further information. In patients with gliomas, PET $\left[{ }^{18} \mathrm{~F}\right]$ fluorodeoxyglucose studies have shown a relation between glucose metabolism and both histological grade ${ }^{130}$ and survival. ${ }^{131}$ It should not be assumed, however, that a lesion with high $\left[{ }^{18} \mathrm{~F}\right]$ fluorodeoxyglucose uptake is necessarily a tumour, as cerebral abscesses may also show increased uptake. ${ }^{132}$ Use has also been made of SPECT in an effort to dif- ferentiate high from low grade gliomas. Thallium-201 (a tracer more familiarly used in myocardial studies) exhibits increased uptake in some tumours. In gliomas, uptake is greater in high grade lesions. ${ }^{133}$

A particular clinical problem in neurooncology is the management of patients presenting with recurrent lesions after radiotherapy for tumour. It can be difficult to differentiate recurrent tumour from radiation induced necrosis on the basis of clinical assessment and structural imaging alone. $\left[{ }^{18} \mathrm{~F}\right]$ Fluorodeoxyglucose PET is of clinical use in this situation, ${ }^{134}$ as recurrent tumour has a high metabolic rate (fig 7), whereas low $\left[{ }^{18} \mathrm{~F}\right]$ fluorodeoxyglucose uptake suggests radionecrosis. ${ }^{135}$ The measurement is not affected in the early postoperative period, nor by steroid treatment. ${ }^{135}$

Other aspects of tumour biochemistry have also been explored with PET, including measurements of amino acid uptake and protein synthesis. $\left[{ }^{11} \mathrm{C}\right]$ Methionine accumulates readily in gliomas, ${ }^{136}$ higher uptake usually occurring in high grade tumours. ${ }^{137}$ DNA synthesis can also be followed with nucleosides such as deoxyuridine labelled with fluorine-18. ${ }^{138}$ Peripheral benzodiazepine $(\omega 3)$ receptors are expressed on human glioma cells; the presence of this tumour marker may be recognised with PET and the specific marker $\left[{ }^{11} \mathrm{C}\right]-\mathrm{PK} 11195 .{ }^{23}$

\section{CLINICAL INDICATION}

The principal consensus use of functional imaging in oncology is in the differentiation of recurrent cerebral glioma from postradiation necrosis.

\section{Summary of clinical indications for functional imaging studies}

As mentioned at the outset of this review, the cornerstone of clinical neuroimaging



Figure 7 PET $\left.{ }^{8} \mathrm{~F}\right]$ fluorodeoxyglucose images from a patient with a recurrent glioma. The PET images (to the left) show increased metabolism indicative of recurrent tumour. (Illustration courtesy of Professor M Maisey.) 
procedures has been the identification of broadly "structural" changes in neural tissue. The tools for such image acquisition ( $x$ ray CT and MRI) are widely available and of increasingly high quality and resolution. As we have so few functional imaging facilities, clinical indications for functional imaging studies must be restricted to situations where CT and MRI fail to answer the clinical question. All of these techniques are presently developing rapidly, with new MRI sequences blurring the structure and function divide and newer PET and SPECT ligands pushing forward the capabilities of functional studies.

At the present time, I list the following sensible clinical indications for functional imaging. To my mind, these are clinical situations in which functional imaging studies can provide clinical information with important therapeutic implications.

- Differentiation of tumour recurrence from radionecrosis (PET/FDG)

- Contribution to presurgical assessment of patients with refractory epilepsy (PET/ FDG, SPECT/flow tracers)

- Differentiation of juvenile Parkinson's disease from dopa responsive dystonia (PET/ $\left[{ }^{18} \mathrm{~F}\right]$ dopa).

Further possibilities of substantial clinical use include:

- Identification of critical gyri or sulci before neurosurgical or neuroradiological procedures (fMRI)

- Neurochemical monitoring of patients undergoing neurotransplantation procedures (PET).

Functional imaging studies can also provide precise information contributing to diagnostic precision in, for example, the dementias and akinetic-rigid syndromes. But whereas functional imaging touches on clinical practice, to my mind its principal strength lies in its position as one of our most powerful instruments for clinical research.

1 Mallett BL, Veall N. Investigation of cerebral blood flow in hypertension, using radioactive-xenon inhalation and extracranial recording. Lancet 1963;i:1081-2.

2 Phelps ME. Positron emission tomography (PET). In: Mazziotta JC, Gilman S, eds. Clinical brain imaging No 39). Philadelphia: F A Davis, 1992:71-107.

3 Lassen NA, Holm S. Single photon emission computed tomography (SPECT). In: Mazziotta JC, Gilman S, (contemporary neurology series No 39). Philadelphia: F A (contemporary neurology

4 Lufkin RB. Magnetic resonance imaging. In: Mazziotta JC, Gilman S, eds. Clinical brain imaging principles and JC, Gilman S, eds. Clinical brain imaging principles and applications (contemporary neurology

5 Prichard JW, Rosen BR. Functional study of the brain by NMR. f Cereb Blood Flow Metab 1994;14:365-72.

6 Cohen MS, Bookheimer SY. Localization of brain function using magnetic resonance imaging. Trends Neurosci 1994;17:268-77.

7 Turner R. Magnetic resonance imaging of brain function. Ann Neurol 1994;35:637-8.

8 Stehling MK, Turner R, Mansfield P. Echo-planar imaging: magnetic resonance imaging in a fraction of a second. Science 1991;254:43-50.

9 Mansfield P, Coxon R, Glover P. Echo planar imaging of the brain at 3.0T: first normal volunteer results. f Comput Assist Tomogr 1994;18:339-43.

10 Haase A, Frahm J, Matthaei D, Hänicke W, Merboldt KD. FLASH imaging: rapid NMR imaging using low flip-angle pulses. I Magn Reson Imaging 1986;67: 258-66.

11 Lammertsma AA, Frackowiak RSJ, Hoffman JM, et al. The $\mathrm{C}^{15} \mathrm{O}_{2}$ build-up technique to measure regional cerebral blood flow and volume of distribution of water. $f$ Cereb Blood Flow Metab 1989;9:461-70.
12 Lammertsma AA, Jones T. Correction for the presence of intravascular oxygen-15 in the steady-state technique for measuring regional oxygen extraction ratio in the b. F Cereb Blood Flow Metab 1983;3:416-24.

13 Rinne JO, Laihinen A, Någren $\mathrm{K}$, et al. PET demonstrates different behaviour of striatal dopamine D-1 and D-2 receptors in early Parkinson's disease. $\mathcal{f}$ Neurosci Res 1990;27:494-9.

14 Sawle GV, Playford ED, Brooks DJ, Quinn N, Frackowiak RSJ. Asymmetrical presynaptic and postsynaptic changes in the striatal dopamine projection in dopa-naïve parkinsonism: diagnostic implications of the D2 receptor status. Brain 1993;116:853-67.

15 Tedroff J, Aquilonius S-M, Hartvig P, et al. Monoamine re-uptake sites in the human brain evaluated in vivo by means of ${ }^{11} \mathrm{C}$-nomifensine and positron emission tomography: the effects of age and Parkinson's disease. tomography: the effects of age and Park

16 Salmon E, Brooks DJ, Leenders KL, et al. A twocompartment description and kinetic procedure for measuring regional cerebral $\left[{ }^{11} \mathrm{C}\right]$ nomifensine uptake using positron emission tomography. F Cereb Blood Flow Metab 1990;10:307-16.

17 Frost JJ, Rosier AJ, Reich SG, et al. Positron emission tomographic imaging of the dopamine transporter with ${ }^{11} \mathrm{C}$-WIN 35,428 reveals marked declines in mild Parkinson's disease. Ann Neurol 1993;34:423-31.

18 Mayberg HS, Sadzot B, Meltzer CC, et al. Quantification of $\mathrm{Mu}$ and non-Mu opiate receptors in temporal lobe epilepsy using positron emission tomography. Ann Neurol 1991;30:3-11.

19 Carson RE, Channing MA, Blasberg RG, et al. Comparison of bolus and infusion methods for receptor quantitation: application to $\left[{ }^{18} \mathrm{~F}\right]$ cyclofoxy and tor quantitation: application to ${ }^{\left[{ }^{18} \mathrm{~F}\right]}$ cyclofoxy and positron emission tom

20 Bartenstein PA, Duncan JS, Prevett MC, et al. Investigation of the opioid system in absence seizures with positron emission tomography. $\mathcal{F}$ Neurol Neurosurg Psychiatry 1993;56:1295-302

21 Price JC, Mayberg HS, Dannals RF, et al. Measurement of benzodiazepine receptor number and affinity in humans using tracer kinetic modelling, positron emission tomography, and $\left[{ }^{11} \mathrm{C}\right]$ flumazenil. 7 Cereb Blood Flow Metab 1993;13:656-67.

22 Ramsay SC, Weiller C, Myers R, et al. Monitoring by PET of macrophage accumulation in brain after ischaemic stroke. Lancet 1992;339:1054-5.

23 Junck L, Olson JMM, Ciliax BJ, et al. PET imaging of human gliomas with ligands for the peripheral benzodihuman gliomas with ligands for the peripheral be

24 Frey KA, Koeppe RA, Mulholland GK, et al. In vivo muscarinic cholinergic receptor imaging in human brain with $\left[{ }^{11} \mathrm{C}\right]$ scopolamine and positron emission tomography. F Cereb Blood Flow Metab 1992;12: 147-54.

25 Yanai K, Watanabe T, Yokoyama $\mathrm{H}$, et al. Mapping of histamine $\mathrm{H}_{1}$ receptors in the human brain using ${ }^{11} \mathrm{C}$ pyrilamine and positron emission tomography. f Neurochem 1992;59:128-6.

26 Lammertsma AA, Bench CJ, Price GW, et al. Measurement of cerebral monoamine oxidase $B$ activity using $L-\left[{ }^{11} \mathrm{C}\right]$ Deprenyl and dynamic positron emission tomography. $\mathcal{F}$ Cereb Blood Flow Metab 1991; 11:545-56.

27 Friston KJ, Frith CD, Liddle PF, Dolan RJ Lammertsma AA, Frackowiak RSJ. The relationship between global and local changes in

28 Friston KJ, Frith CD, Liddle PF, Frackowiak RSJ Comparing functional (PET) images: the assessment of significant change. I Cereb Blood Flow Metab 1991, 11:690-9.

29 Watson JDG, Myers R, Frackowiak RSJ, et al. Area V5 of the human brain: evidence from a combined study using positron emission tomography and magnetic resonance imaging. Cereb Cortex 1993;3:79-94.

30 Winchell HS, Baldwin RM, Lin TH. Development of -123 labelled amines for brain studies: Localization of I-123 iodophenylalkylamines in rat brain. 7 Nucl Med 1980;21:940.

31 Greenberg JH, Lassen NA. Characterization of $99 \mathrm{~m} T \mathrm{Tc}-$ Bicasate as an agent for the measurement of cerebral blood flow with SPECT. $f$ Cereb Blood Flow Metab 1994;14(suppl 1):S1-S3.

32 1994;14(suppl 1):S1-S3. IR, Bydder GM. Artifacts due to stimulus correlated motion in functional imaging of the brain. Magn Reson motion in functional

33 Woods RP, Cherry SR, Mazziotta JC. Rapid automated algorithm for aligning and reslicing PET images. f Comput Assist Tomogr 1992;115:565-87.

34 Tyszka JM, Grafton ST, Chew W, Woods RP, Colletti PM. Parceling of mesial frontal motor areas during ideation and movement using functional magnetic resonance imaging at 1.5 Tesla. Ann Neurol 1994;35: $746-9$.

35 Wise RJS, Bernardi S, Frackowiak RSJ, et al. Serial observations on the pathophysiology of acute stroke: the transition from ischaemia to infarction as reflected in regional oxygen extraction. Brain 1983;106: in region.

36 Gibbs JM, Wise RJS, Leenders KL, Jones T. Evaluation of the cerebral reserve in patients with carotid artery occlusion. Lancet 1984;i:310-4.

37 Kushner M, Reivich M, Fieschi C, et al. Metabolic and 
clinical correlates of acute ischaemic infarction. Neurology 1987;37:1103-10.

38 Chollet F, DiPiero V, Wise RJS, Brooks DJ, Dolan RJ, Frackowiak RSJ. The functional anatomy of motor recovery after stroke in humans: a study with positron emission tomography. Ann Neurol 1991;29:63-71.

39 Weiller C, Chollet F, Friston KJ, Wise RJS, Frackowiak RSJ. Functional reorganization of the brain in recovery from striatocapsular infarction in man. Ann Neurol 1992;31:305-14

40 Baron JC, Bousser MG, Rey A, et al. Reversal of focal "misery-perfusion" by extra-intracranial artery bypas in haer

41 Gibbs JM, Wise RJS, Thomas DJ, Mansfield AO, Ross Russell RW. Cerebral haemodynamic changes after Russell RW. Cerebral haemodynamic changes after
extracranial-intracranial bypass surgery. $f$ Neurol extracranial-intracranial bypass surge
Neurosurg Psychiatry 1987;50:140-50.

42 EC-IC bypass study group. Failure of extracranialintracranial bypass to reduce the risk of ischaemic stroke: Results of an international randomised trial. $N$ Engl F Med 1985;313:1 191-200.

43 Humphrey $P$. Stroke and transient ischaemic attacks. f Neurol Neurosurg Psychiatry 1994;57:534-43.

44 Frackowiak RSJ, Pozzilli C, Legg NJ, et al. Regiona cerebral oxygen supply and utilization in dementia. A
clinical and physiological study with oxygen-15 and positron tomography. Brain 1981;104:753-78.

45 Foster NL, Chase TN, Fedio P, Patronas NJ, Brooks RA, DiChiro G. Alzheimer's disease: focal cortical changes shown by positron emission tomography. changes shown by posit
Neurology 1983;33:961-5.

46 Neurology 1983;33:961-5. Heiss W-D. Criteria for the diagnosis of Alzheimer's disease with positron emission tomography. Dementia 1990;1:156-64

47 Kumar A, Schapiro M, Grady C, et al. High-resolution PET studies in Alzheimer's disease. Neuropsychopharmacology 1991;4:35-46.

48 Haxby JV, Grady CL, Koss E, et al. Heterogeneous anterior-posterior metabolic patterns in dementia of the Alzheimer-type. Neurology 1988;38:1853-63.

49 Foster NL, Chase TN, Patronas NJ, Gillespie MM, Fedio P. Cerebral mapping of apraxia in Alzheimer's disease by positron emission tomography. Ann Neurol 1986;19:139-43.

50 Kuhl DE, Small GW, Reige WH. Cerebral metabolic patterns before the diagnosis of probable Alzheimer's patterns before the diagnosis of probable Alzh
disease. F Cereb Blood Flow Metab 1987;7:S406.

51 Montaldi D, Brooks DN, McColl JH, et al. Measurements of regional cerebral blood flow and cognitive performance in Alzheimer's disease. $f$ Neurol nitive performance in Alzheimer's
Neurosurg Psychiatry 1990;53:33-8.

52 Burns A, Philpot MP, Costa DC, Ell PJ, Levy R. The investigation of Alzheimer's disease with single photon emission tomography. If Neurol Neurosurg Psychiatry 1989;52:248-53.

53 Waldemar G, Bruhn P, Kristensen M, Johnsen A Paulson OB, Lassen NÁ. Heterogeneity of neocortical cerebral blood flow deficits in dementia of the Alzheimer type: a [99m Tc]-d,l-HMPAO SPECT study. $\mathcal{f}$ Neurol Neurosurg Psychiatry 1994;57:285-95.

54 Kennedy AM, Frackowiak RSJ, Newman S, Roques P, Rossor MN. Presymptomatic deficits in individuals at risk of familial Alzheimer's disease: a PET study. Ann Neurol 1995 (in press)

55 Kamo H, McGeer PL, Harrop R, et al. Positron emission tomography and histopathology in Pick's disease. Sion tomography and histo

56 Salmon E, Franck G. Positron emission tomographic study in Alzheimer's disease and Pick's disease. study in Alzheimer's disease and Pick's diseas
Archives of Gerontology and Geriatrics 1989;8:241-7.

57 Leenders KL, Frackowiak RSJ, Lees AJ. SteeleRichardson-Olszewski syndrome. Brain energy metab olism, blood flow and fluorodopa uptake measured by positron emission tomography. Brain 1988;111: 615-30.

58 Karbe $H$, Grond $M$, Huber $M$, Herholz $K$, Kessler J, Heiss W-D. Subcortical damage and cortical dysfunction in progressive supranuclear palsy demonstrated by positron

59 Foster NL, Gilman S, Berent S, Morin EM, Brown MB Koeppe RA. Cerebral hypometabolism in progressive supranuclear palsy studied with positron emission supranuclear palsy studied with positro

60 Neary D, Snowden JS, Shields RA, et al. Single photon emission tomography using ${ }^{99 m}$ Tc-HM-PAO in the investigation of dementia. $\mathcal{F}$ Neurol Neurosurg Psychiatry investigation of

61 Tyrrell PJ, Warrington EK, Frackowiak RSJ, Rosso MN. Progressive degeneration of the right temporal lobe studied with positron emission tomography f Neurol Neurosurg Psychiatry 1990;53:1046-50.

62 Tyrrell PJ, Warrington EK, Frackowiak RSJ, Rosso $M N$. Heterogeneity in progressive aphasia due to focal cortical atrophy: A clinical and PET scan study. Brain 1990;113:1321-36.

63 Kuhl DE, Phelps ME, Markham CH, Metter EJ, Riege WH, Winter EJ. Cerebral metabolism and atrophy in Huntington's disease determined by $18 \mathrm{FDG}$ and computed tomographic scans. Ann Neurol 1982;12:425-34.

64 Hayden MR, Martin WRW, Stoessl AJ, et al. Positron emission tomography in the early diagnosis of Huntington's disease. Neurology 1986;36:888-94.
65 Grafton ST, Mazziotta JC, Pahl JJ, et al. A comparison of neurological, metabolic, structural, and genetic evaluations in persons at risk for Huntington's disease. Ann Neurol 1990;28:614-21.

66 Mazziotta JC, Phelps ME, Pahl J, et al. Reduced glucose metabolism in asymptomatic subjects at risk for Huntington's disease. $N$ Engl F Med 1987;316:357-62.

67 The Huntington's disease collaborative research group. A novel gene containing a trinucleotide repeat that is expanded and unstable in Huntington's disease chromosomes. Cell 1993;72:971-83.

68 MacMillan JC, Snell RG, Tyler A, et al. Molecular analysis and clinical correlations of the Huntington's disease mutation. Lancet 1993;342:954-8.

69 Aylward EH, Brandt J, Codori AM, Mangus RS, Barta PE, Harris GJ. Reduced basal ganglia volume associated with the gene for Huntington's disease in asympated with the gene for Huntington's disease in as
tomatic at-risk persons. Neurology 1994;44:823-8.

tomatic at-risk persons. Neurology 1994;44:823-8.
70 Kuhl DE, Metter EJ, Riege WH. Patterns of local cerebral glucose utilisation determined in Parkinson's disease by the $18 \mathrm{~F}$-fluorodeoxyglucose method. Ann Neurol 1984;15:419-24.

71 Raichle ME, Perlmutter JS, Fox PT. Parkinson's disease: metabolic and pharmacological approaches with positron emission tomography [abstract]. Ann Neurol 1984;15:S131-2.

72 Martin WRW, Beckman JH, Calne CB, et al. Cerebral glucose metabolism in Parkinson's disease. Can $\mathcal{f}$ Neurol Sci 1984;11:169-73.

73 Leenders KL, Palmer AJ, Quinn $\mathrm{N}$, et al. Brain dopamine metabolism in patients with Parkinson's disease measured with positron emission tomography. ease measured with positron emission tom
f Neurol Neurosurg Psychiatry 1986;49:853-60.

74 Sawle GV, Colebatch JG, Shah A, Brooks DJ, Marsden CD, Frackowiak RSJ. Striatal function in normal aging: Implications for Parkinson's disease. Ann Neurol aging: Implication

75 Eidelberg D, Takikawa S, Dhawan V, et al. Striatal ${ }^{18} \mathrm{~F}$ DOPA uptake: absence of an aging effect. $\mathcal{F}$ Cereb Blood Flow Metab 1993;13:881-8.

76 Martin WRW, Palmer MR, Patlak CS, Calne DB. Nigrostriatal function in humans studied with positron emission tomography. Ann Neurol 1989;26:535-42.

77 Sawle GV, Wroe SJ, Lees AJ, Brooks DJ, Frackowiak RSJ. The identification of presymptomatic parkinsonism: clinical and [ $18 \mathrm{~F}]$ Dopa PET studies in an Irish kindred. Ann Neurol 1992;32:609-17.

78 Sawle GV, Turjanski N, Brooks DJ. The rate of progression of clinical and subclinical Parkinson's disease. f Neurol Neurosurg Psychiatry 1992;55:1215.

79 Bhatt MH, Snow BJ, Martin WRW, Pate BD, Ruth TJ, Calne DB. Positron emission tomography suggests that
Catt Calne DB. Positron emission tomography suggests that the rate of progression of idiop
slow. Ann Neurol 1991;29:673-7.

80 Sawle GV. The rate of progression of Parkinson's disease. Ann Neurol 1992;31:229.

81 Sawle GV, Myers R. The role of positron emission tomography in the assessment of human neurotransplantation. Trends Neurosci 1993;16:172-6.

82 Widner H, Tetrud J, Rehncrona S, et al. Bilateral fetral mesencephalic grafting in two patients with parkinsonism induced by 1-methyl-4-phenyl-1,2,3,6-tetrahydropyridine (MPTP). $N$ Engl $f$ Med 1992;327: $1556-63$.

83 Brooks DJ, Salmon EP, Mathias CJ, et al. The relationship between locomotor disability, autonomic dysfunction, and the integrity of the striatal dopaminergic tion, and the integrity of the striatal dopaminergic
system in patients with multiple system atrophy, pure system in patients with multiple system atrophy, pure
autonomic failure, and Parkinson's disease, studied autonomic failure, and Parkinson's
with PET. Brain 1990;113:1539-52.

84 Brooks DJ, Ibañez V, Sawle GV, et al. Differing patterns of striatal 18F-dopa uptake in Parkinson's disease, multiple system atrophy and progressive supranuclear palsy. Ann Neurol 1990;28:547-55

85 Bhatt MH, Snow BJ, Martin WRW, Cooper S, Calne DB. Positron emission tomography in Shy-Drager syndrome. Ann Neurol 1990;28:101-3.

86 Sawle GV, Brooks DJ, Marsden CD, Frackowiak RSJ. Corticobasal degeneration: a unique pattern of regional cortical oxygen metabolism and striatal fluorodopa uptake demonstrated by positron emission tomography. Brain 1991;114:541-56.

87 Brooks DJ, Ibanez V, Playford ED, et al. Presynaptic and postsynaptic striatal dopaminergic function in neuroacanthocytosis: a positron emission tomographic study. Ann Neurol 1991;30:166-71.

88 Calne DB, Langston JW, Martin WRW, et al. Positron emission tomography after MPTP: observations relatemission tomography after MPTP: observations relating to the cause

89 Burn DJ, Sawle GV, Brooks DJ. Differential diagnosis of Parkinson's disease, multiple system atrophy, and Steele-Richardson-Olszewski syndrome: discriminant function analysis of striatal ${ }^{18} \mathrm{~F}$-dopa PET data. f Neurol Neurosurg Psychiatry 1994;57:278-84

90 Tyrrell PJ, Sawle GV, Bloomfield PM, et al. Clinical and PET studies in the extrapyramidal syndrome of dementia of the Alzheimer type. Arch Neurol 1990; 47:1318-23.

91 Sawle GV, Hymas NF, Lees AJ, Frackowiak RSJ. Obsessional slowness: functional studies with positron emission tomography. Brain 1991;114:2191-202.

92 Wolters ECh, Huang C, Clark C, et al. Positron emission tomography in manganese intoxication. Ann Neurol 1989;26:647-51. 
93 Rosenberg NL, Myers JA, Martin WR. Cyanide-induced parkinsonism: clinical, MRI, and 6-fluorodopa PET parkinsonism: clinical, MRI, and

94 Burn DJ, Brooks DJ. Nigral dysfunction in drug-induced parkinsonism: An ${ }^{18} \mathrm{~F}$-dopa PET study. Neurology 1993;43:552-6.

95 Tedroff J, Aquilonius S-M, Laihinen A, et al. Striatal kinetics of $\left[{ }^{11} \mathrm{C}\right]-(+)$-nomifensine and $6-\left[{ }^{18} \mathrm{~F}\right]$ fluoro-L dopa in Parkinson's disease measured with positro emission tomography. Acta Neurol Scand 1990;81: 24-30.

96 Hantraye $\mathrm{P}$, Brownell AL, Elmaleh $\mathrm{D}$, et al. Dopamine fiber detection by $\left[{ }^{11} \mathrm{C}\right]-\mathrm{CFT}$ and PET in a primate

97 Marek KL, Seibyl JP, Sandridge B, et al. SPECT imag ing with [I-123] $\beta$-CIT demonstrates striatal dopamine


transporter loss
(suppl 2):A352.

98 Hagglund J, Aquilonius S-M, Eckernas S-A, et al. Dopamine receptor properties in Parkinson's disease and Huntington's chorea evaluated by positron emission tomography using ${ }^{11} \mathrm{C}-\mathrm{N}$

99 Wienhard K, Coenen HH, Pawlik G, et al. PET studies of dopamine receptor distribution using $[(18) \mathrm{F}]$ fluoroethylspiperone: findings in disorders related to the dopaminergic system. F Neural Transm 1990;81: 195-213.

100 Rinne UK, Laihinen A, Rinne JO, Nagren K, Bergman J, Ruotsalainen U. Positron emission tomography demonstrates dopamine D-2 receptor supersensitivity in the striatum of patients with early Parkinson's disease. Mov Disord 1990;5:55-9.

101 Rinne JO, Laihinen A, Rinne UK, Någren K, Bergman J, Ruotsalainen U. PET study on striatal dopamine D Ruotsalainen U. PET study on striatal dopamine $\mathbf{D}_{2}$ receptor changes during the progression of

102 Brücke T, Podreka I, Angelberger P, et al. Dopamine D2 receptor imaging with SPECT: studies in differen neuropsychiatric disorders. $\mathcal{f}$ Cereb Blood Flow Metab 1991;11:220-8.

103 Tatsch K, Schwarz J, Oertel WH, Kirsch C-M. SPECT imaging of dopamine D2 receptors with 123I-IBZM: initial experience in controls and patients with Parkinson's syndrome and Wilson's disease. Nucl Med Commun 1991;12:699-707.

104 Pizzolatto G, Rosatto A, Briani C, et al. Alterations of striatal D2 receptors contribute to deteriorated response to L-dopa in Parkinson's disease (PD): a ${ }^{123}$ IIBZM study. Neurology 1993;43(suppl):A271.

105 Scharz J, Tatsch K, Arnold G, et al. ${ }^{123}$ I-iodobenzamide-SPECT predicts dopaminergic responsiveness in mide-SPECT predicts dopaminergic responsiveness in patients with

106 Burn DJ, Mathias CJ, Quinn N, Marsden CD, Brooks DJ. Striatal opiate receptor binding in Parkinson's disease and multiple system atrophy: "C-diprenorphin study. Neurology 1993;43(suppl):A270.

107 Gilman S, Koeppe RA, Junck L, Kluin KJ, Lohman M St Laurent RT. PET studies of cerebellar bensodiazepine receptors with $\left[{ }^{11} \mathrm{C}\right]$ flumazenil show increased binding in MSA and decreased binding in OPCA Neurology 1994;44:(suppl 6):A353.

108 Mayberg HS, Starkstein SE, Sadzot B, et al. Selective hypometabolism in the inferior frontal lobe in depressed patients with Parkinson's disease. Ann depressed patients

109 Eidelberg D, Moeller JR, Dhawan V, et al. The metabolic anatomy of Parkinson's disease: Complementary bolic anatomy of Parkinson's disease: Complementary
[(18)F] fluorodeoxyglucose and [(18)]fluorodopa [(18)F] fluorodeoxyglucose and [(18)] fluorodopa positron emission

110 Playford ED, Jenkins IH, Passingham RE, Nutt J, Frackowiak RSJ, Brooks DJ. Impaired mesial fronta and putamen activation in Parkinson's disease: A positron emission tomography study. Ann Neurol 1992 32:151-61

111 Jenkins IH, Fernandez W, Playford ED, et al. Impaired activation of the supplementary motor area in Parkinson's disease is reversed when akinesia is treated with apomorphine. Ann Neurol 1992;32:749-57.

112 Rascol O, Sabatini U, Chollett F, et al. Supplementary and primary sensory motor area activity in Parkinson's disease. Arch Neurol 1992;49:144-8.

113 Rao SM, Binder JR, Bandettini PA, et al. Functiona magnetic resonance imaging of complex human movemagnetic resonance imaging of comp.
114 Rao SM, Binder JR, Bandettini PA, et al. Relationship between movement rate and functional magnetic resonance signal change in primary motor cortex. Neurolog 1994;44(suppl 2):A262.

115 Turjanski N, Burn DJ, Lammertsma AA, et al. PET studies on $\mathrm{D} 1$ and $\mathrm{D} 2$ receptor status in chorea. Neurology 1993;43:A333.

116 Nygaard TG, Marsden CD, Fahn S. Dopa-responsive dystonia: long term treatment, response and prognosis. Neurology 1991;41:174-81.

117 Quinn N, Critchley P, Marsden CD. Young onset Parkinson's disease. Mov Disord 1987;2:73-91.

118 Sawle GV, Leenders KL, Brooks DJ, et al. Dopa-responsive dystonia: [18F] dopa positron emission tomography. Ann Neurol 1991;30:24-30.

119 Snow BJ, Nygaard TG, Takahashi H, Calne DB. Positron emission tomographic studies of dopa-responPositron emission tomographic studies of dopa-responsive dystonia and early-onset

120 Sawle GV, Morrish PK, Playford ED, Burn DJ, Brooks DJ. Young-onset parkinsonism: clues from $\left[{ }^{18} \mathrm{~F}\right] \mathrm{dopa}$ PET studies. Neurology 1994;44(suppl 2):A353-4.

121 Engel J, Kuhl DE, Phelps ME, Mazziotta JC. Interictal cerebral glucose metabolism in partial epilepsy: its relation to EEG changes. Ann Neurol 1982;12:510-7.

122 Theodore WH, Newmark ME, Sato S, et al. ${ }^{18} \mathrm{~F}$-fluorodeoxyglucose positron emission computed tomography in refractory complex partial seizures. Ann Neurol 1983;14:429-37.

123 Abou-Khalil BW, Siegel GJ, Sackellares JC, Gilman S, Hichwa RD, Marshall R. Positron emission tomography studies of cerebral glucose metabolism in chronic partial epilepsy. Ann Neurol 1987;22:480-6.

124 Theodore WH, Jabbari B, Leiderman D, McBurney J Van Nostrand D. Positron emission tomography and single photon emission tomography in epilepsy: com-
parison on cerebral blood flow and glucose metaboparison on cerebral blood flow

125 Engel J, Kuhl DE, Phelps ME. Patterns of human local cerebral glucose metabolism during epileptic seizures. Science 1982;218:64-6.

126 Ryvlin P, Philippon B, Cinotti L, Froment JC, Le Bar $D$, Mauguière $F$. Functional neuroimaging strategy in temporal lobe epilepsy: a comparative study of ${ }^{18} \mathrm{FDG}-$ 31: $650-6$.

127 Sadzot B, Debets R, Maquet P, Comar C, Franck G PET studies of patients with partial epilepsy: visual interpretation vs. semi-quantitation/quantitation. Acta Neurol Scand Suppl 1994;152:175-8.

128 Duncan R, Patterson J, Hadley DM, et al. CT, MR and SPECT imaging in temporal lobe epilepsy. $\mathcal{F}$ Neurol Neurosurg Psychiatry 1990;53:11-5.

129 Jackson GD, Connelly A, Cross JH, Gordon I, Gadian DG. Functional magnetic resonance imaging of focal seizures. Neurology 1994;44:850-6.

$130 \mathrm{Di}$ Chiro G, DeLaPaz RL, Brooks RA, et al. Glucose utilization of cerebral gliomas measured by $\left[{ }^{18} \mathrm{~F}\right]$ fluorodeoxyglucose and positron emission tomography. Neurology 1982;32:1323-9.

131 Patronas NJ, Di Chiro G, Kufta C, et al. Prediction of survival in glioma patients by PET. I Neurosurg 1985 62:816-22.

132 Sasaki M, Ichiya Y, Kuwabara Y, et al. Ringlike uptake of [(18)F]FDG in brain abscess: A PET study. f Comput Assist Tomog 1990;14:486-7.

$133 \mathrm{Kim}$ KT, Black KL, Marciano D, et al. Thalium-201 SPECT imaging of brain tumours. $f \mathrm{Nucl} \mathrm{Med}$ 1990;31:965-9.

134 Mazziotta JC. The continuing challenge of primary brain tumour management: the contribution of positron tumour management: the contribution of positr

135 Glantz MJ, Hoffman JM, Coleman RE, et al. Identification of early recurrence of primary centra nervous system tumours by $\left[{ }^{18} \mathrm{~F}\right]$ fluorodeoxyglucose positron emission tomography. Ann Neurol 1991;29: $347-55$.

136 Hatazawa J, Ishiwata $\mathrm{K}$, Itoh $\mathrm{M}$, et al. Quantitative evaluation of L-[methyl-C-11]methionine uptake in tumo using positron emission tomography. $\mathrm{F}$ Nucl Med 1989; 30:1809-13.

137 Bustany $\mathrm{P}$, Chatel M, Derlon M, et al. Brain tumour protein synthesis and histological grades: a study by positron emission tomography (PET) and C-11-I methionine. I Neurooncol 1986;3:397-404.

138 Tsurumi $\mathrm{Y}$, Kameyama $\mathrm{M}$, Ishiwata $\mathrm{K}$, et al. (18)F-fluoro-2'-deoxyuridine as a tracer of nucleic acid metabolism in brain tumors. $₹$ Neurosurg 1990;72:110-3. 